Brit. Heart F., 1968, 30, 676.

\title{
Chronic Haemolysis Following Insertion of Ball Valve Prostheses
}

\author{
M. H. YACOUB ${ }^{\star}$ AND D. H. KEELING \\ From The Brompton Hospital, London S.W.3, and The Middlesex Hospital Medical School, London W.1
}

Intravascular haemolysis after the insertion of intracardiac prosthetic material has been reported by Sayed et al. (1961), Verdon, Forrester, and Crosby (1963), Sigler et al. (1963), Gehrmann and Loogen (1964), Reed and Dunn (1964), Marsh (1964), and Yacoub, Rogers, and Taylor (1965). The haemolysis may be sufficient to produce clinical haemolytic anaemia or may cause a compensated haemolytic state (Yacoub et al., 1965). The possible harmful effects of mild continuous chronic haemolysis on the kidney and liver have been pointed out by Song (1957) and by Andersen, Gabrieli, and Zizzi (1965). The purpose of this paper is to study red cell survival after the insertion of Starr-Edwards prostheses in the aortic and mitral areas.

\section{SUBJECTS AND METHODS}

Studies were made of 28 patients: the aortic valve was replaced in 15 (Cases 1-15), the mitral valve in 11 (Cases 18-28), and both aortic and mitral valves in 2 (Cases 16 and 17). All patients had clinically competent valves except 8 (Cases $1-5,7,16$, and 18) who had mild to moderate regurgitation around the prosthesis. One patient (Case 6) had evidence of residual obstruction at aortic valve level, which was thought to be due to the small size of the aortic root leading to inadequate space around the ball of the aortic prosthesis.

Blood taken from each patient was heparinized, and the red cells were separated. These were labelled in vitro with approximately $75 \mu \mathrm{Ci}$ of ${ }^{51} \mathrm{Cr}$ sodium chromate at room temperature. The cells were then washed three times and reconstituted to original volume with normal saline before intravenous injection. Blood samples were taken over a period of at least one half-life ( $\left.\mathrm{T} \frac{1}{2}\right)$ of the cells, and ${ }^{51} \mathrm{Cr}$ activity was counted in a well-type scintillation detector. The results, uncorrected for elution of label, were plotted on semilog paper. After the first 24 hours, the plot closely approximates a straight line, whose slope gives the half-life of the labelled cells

Received January 17, 1968.

$\star$ Present address: National Heart Hospital, Westmoreland St., London W.1. in the circulation. Using this technique in normal subjects we have found that the half-life of ${ }^{51} \mathrm{Cr}$-labelled cells $\left(\mathrm{T} \frac{1}{2}{ }^{51} \mathrm{Cr}\right.$ ) lies between 25 and 34 days. The estimations were made at periods between 2 and 18 months after operation.

\section{RESULTS}

The Figure shows the red cell survival time in the patients studied. The $\mathrm{T} \frac{1}{2}{ }^{51} \mathrm{Cr}$ of patients with aortic valve prostheses varied between 13 and 26 days, with an average of 20.5 days. Patients who had clinical evidence of regurgitation around the prosthesis had the shortest red cell survival time, with an average $\mathrm{T}^{\frac{1}{2}}{ }^{51} \mathrm{Cr}$ of only 17 days. The degree of haemolysis was also marked in one patient (Case 6) who had evidence of residual obstruction. The $T \frac{1}{2}{ }^{51} \mathrm{Cr}$ in patients with mitral valve prostheses varied between 20.5 days and 29 days, with an average of 25 days. As with aortic valve replacement, the shortest red cell survival was found in the one patient with evidence of regurgitation around the prosthesis.

\section{Discussion}

Haemolytic anaemia after intracardiac operations was first described in relation to Teflon patches used to repair ostium primum defects (Sayed et al., 1961; Verdon et al., 1963; Sigler et al., 1963). This was thought to be due to damage to the red cells by the impact of the mitral regurgitant jet against the surface of the Teflon patch (Sayed et al., 1961). Haemolytic anaemia has also been described after aortic valve replacement, using the Hufnagel Dacron prosthesis (Gehrmann and Loogen, 1964; DeCesare, Rath, and Hufnagel, 1965), the Bahnsen Teflon prosthesis (Yeh, Ellison, and Wright, 1965), the Muller Teflon prosthesis (Rubinson, Morrow, and Gebel, 1966), the Gott-Daggett Teflon valve (Schade et al., 1967), and the Starr-Edwards ball 676 


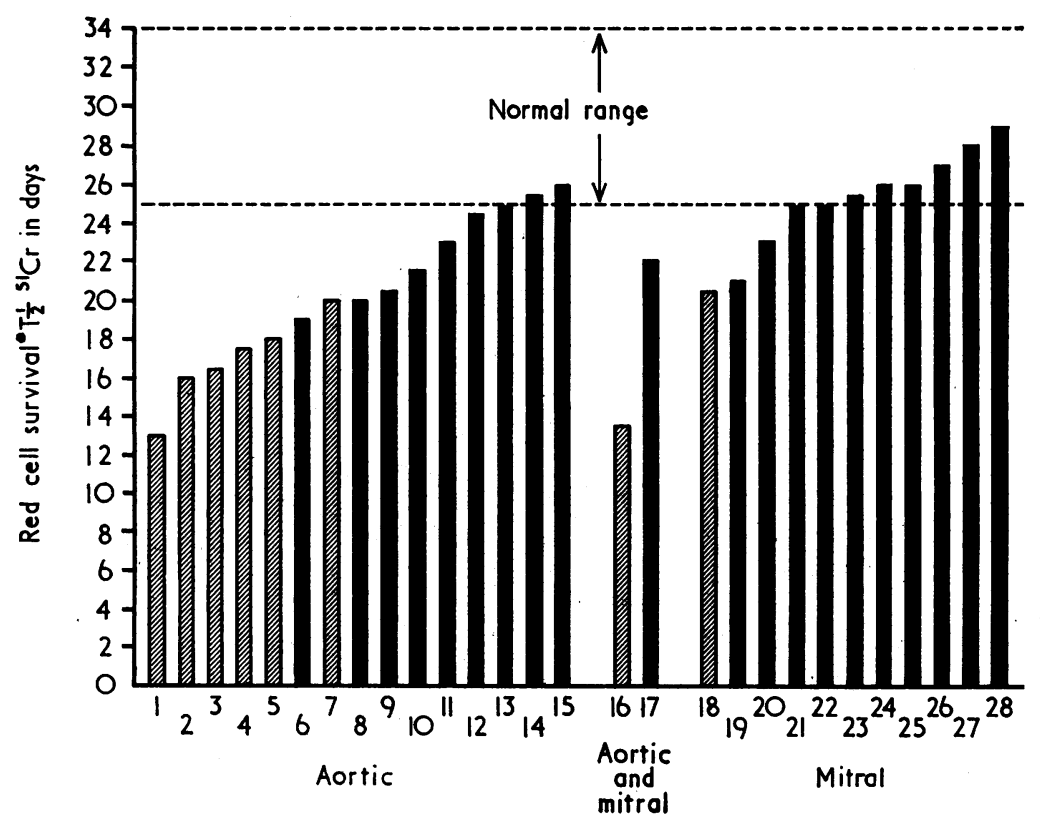

FIG.-Red cell survival in 28 patients following replacement of the aortic, aortic and mitral, or mitral valve by a Starr-Edwards prosthesis. The black columns indicate patients in whom the valve was competent. The cross-hatched columns indicate patients with clinical evidence of regurgitation.

1964; Reed and Dunn, 1964). In all these patients there was evidence of regurgitation through or around the prosthesis. Correction of the leak resulted in immediate correction of the anaemia in the patients described by Gehrmann and Loogen (1964) and Yeh et al. (1965). Red cell survival in patients with a competent McGoon's aortic valve prosthesis was in the lower part of the normal range (Yacoub et al., 1965), though the average red cell half-life with residual regurgitation around these valves was below normal.

In the present series 7 patients developed chronic haemolytic anaemia after operation. All these patients had evidence of regurgitation around the prosthesis. An additional patient (Case 7) had clinical evidence of mild aortic regurgitation after operation, but haemoglobin and packed cell volume remained normal. Patients with competent aortic valve prostheses had no anaemia, but their red cell survival was significantly shortened. Patients with competent mitral valve prostheses had red cell survival times in the lower range of normal or just below. This difference is probably due to the rapid forceful ejection of blood through the aortic valve prosthesis, in contrast to the less turbulent flow through the mitral prosthesis. The degree of haemolysis also depends on the presence or absence of residual haemodynamic defect. Patients with residual regurgitation had the shortest red cell survival. One patient (Case 6) who had residual obstruction by the ball of the prosthesis also had a reduced red cell survival.

The long-term effects of chronic haemolysis in producing organ dysfunction are not known. Normally, free haemoglobin in plasma is bound to haptoglobin: the resulting molecule is too big to be filtered by the kidney (Lathem, 1959). In chronic haemolysis, the binding capacity of haptoglobin may be saturated so that free haemoglobin is filtered by the glomeruli and its reabsorption results in haemosiderosis. Haptoglobin was absent from the plasma of patients with an aortic Starr-Edwards prosthesis (Andersen et al., 1965). Renal haemosiderosis has been demonstrated in patients suffering from paroxysmal nocturnal haemoglobinuria and hereditary spherocytosis (Leonardi and Ruol, 1960) as well as in patients with haemolytic anaemia associated with leaking aortic valve prostheses (Roberts and Morrow, 1966). The latter authors examined the kidney of a patient who died four months after aortic valve replacement by a StarrEdwards prosthesis; the valve was competent at necropsy, but large quantities of iron were present in the kidneys. In all these patients haemosiderin was mainly present in the cells of the proximal convoluted tubules, with few deposits in the cells of the loop of Henle and the epithelial cells lining Bowman's capsule, and none in the interstitial 
tissue. There was no inflammatory or fibrous reaction. This distribution of iron is characteristic of chronic intravascular haemolysis, and is thought to be due to the active reabsorption of haemoglobin by the proximal tubules.

The effect of haemosiderosis on kidney function has not been sufficiently studied. In this condition Leonardi and Ruol (1960) found that the ability to concentrate urine was at the lower level of normal, but so far no gross defects have been attributed to renal tubular haemosiderosis.

\section{SUMMARY}

The degree of chronic haemolysis produced by intracardiac ball valve prostheses (Starr-Edwards) has been studied in 28 patients using ${ }^{51} \mathrm{Cr}$ tagged red cells. Patients with mitral valve prostheses had a red cell survival time within the normal range or just below. Patients with aortic valve prostheses had a significantly shortened red cell survival time, and this was more marked in patients who had a residual haemodynamic defect. Seven patients developed clinical haemolytic anaemia, and all had residual aortic regurgitation. The possible effects of chronic haemolysis on the kidney are discussed.

\section{REFERENCES}

Andersen, M. N., Gabrieli, E., and Zizzi, J. A. (1965). Chronic hemolysis in patients with ball-valve prostheses. F. thorac. Surg., 50, 501.

DeCesare, W., Rath, C., and Hufnagel, C. (1965). Hemolytic anemia of mechanical origin with aortic-valve prosthesis. New Engl. F. Med., 272, 1045.

Gehrmann, G., and Loogen, F. (1964). Mechanische hämolytische Anämie nach Implantation Künstlicher Aortenklappen. Dtsch. med. Wschr., 89, 625.
Lathem, W. (1959). The renal excretion of hemoglobin; Regulating mechanisms and the differential excretion of free and protein-bound hemoglobin. $\mathcal{F}$.clin. Invest., 38, 652 .

Leonardi, P., and Ruol, A. (1960). Renal hemosiderosis in the hemolytic anemias. Diagnosis by means of needle biopsy. Blood, 16, 1029.

Marsh, G. W. (1964). Intravascular haemolytic anaemia after aortic-valve replacement. Lancet, 2, 986.

Reed, W. A., and Dunn, M. (1964). Fatal hemolysis following ball valve replacement of the aortic valve. f. thorac. Surg., 48, 436.

Roberts, W. C., and Morrow, A. G. (1966). Renal hemosiderosis in patients with prosthetic aortic valves. Circulation, 33, 390.

Rubinson, R. M., Morrow, A. G., and Gebel, P. (1966). Mechanical destruction of erythrocytes by incompetent aortic valvular prostheses. Clinical, hemodynamic, and hematologic findings. Amer. Heart f., 71, 179.

Sayed, H. M., Dacie, J. V., Handley, D. A., Lewis, S. M. and Cleland, W. P. (1961). Haemolytic anaemia of mechanical origin after open heart surgery. Thorax, 16, 356.

Schade, S. G., Rowe, G. G., Young, W. P., Lockey, S. D., and Clatanoff, L. V. (1967). Intravascular hemolysis with the Gott-Daggett valve. F. thorac. Surg., 53, 605.

Sigler, A. T., Forman, E. N., Zinkham, W. H., and Neill, C. A. (1963). Severe intravascular haemolysis following surgical repair of ostium primum defects. Amer. $\mathcal{F}$. Med., 35, 467.

Song, Y. S. (1957). Hepatic lesions in sickle cell anemia. Amer. F. Path., 33, 331.

Stevenson, T. D., and Baker, H. J. (1964). Haemolytic anaemia following insertion of Starr-Edwards valve prosthesis. Lancet, 2, 982.

Verdon, T. A., Forrester, R. H., and Crosby, W. H. (1963). Hemolytic anemia after open-heart repair of ostiumprimum defects. New Engl. F. Med., 269, 444.

Yacoub, M. H., Rogers, K., and Taylor, P. C. (1965). Red cell survival in patients with aortic valve disease. Thorax, 20, 367.

Yeh, T. J., Ellison, R. G., and Wright, C. S. (1965). Hemolytic anemia due to a ruptured prosthetic aortic cusp. f. thorac. Surg., 49, 963. 